\title{
強誘電体薄膜研究の最近の展開
}

\author{
正 員 奥山 雅則*
}

\section{Recent Research Development of Ferroelectric Thin Films}

Masanori Okuyama*, Member

\begin{abstract}
Recent research development of ferroelectric thin films has been introduced from the viewpoint of various electronic device application such as nonvolatile memory, infrared sensor, piezoelectric transducers and electrooptic devices. Explained materials of the ferroelectric thin films are PZT, Bi-layer-structured ferroelectrics, $\mathrm{BiFeO}_{3}, \mathrm{YMnO}_{3}$ and $\mathrm{P}(\mathrm{VDF}-\mathrm{TrFE})$.
\end{abstract}

キーワード : 強誘電体薄膜, 不揮発性メモリ, センサ, トランスデューサ, マルチフェロイック

Keyword : ferroelectric thin films, nonvolatile memory, sensor, transducer, multiferroic

\section{1. はじめに}

強誘電体薄膜の作製，微視的構造や物性の解明，電子デ バイス応用はここ20 数年急速に発展してきた。これはとり もなおさず，分極履歴現象を利用した強誘電体不揮発性メ モリ FeRAM 開発のための膨大な研究によるところが大き い。この中で分極反転繰り返しによる分極履歴の劣化 “疲 労”，電界がシフトする “インプリント”，膜厚が小さくな ると強誘電性を失うという“サイズ効果”などの多くの問 題点は解決されたり, その要因が解明されつつある。これ らの研究開発により, FeRAM は高速, 低消費電力の特長を をもつ不揮発性メモリとして新たな市場を創出している。

この FeRAM は強誘電体薄膜の分極履歴現象を用いた典 型的な電子デバイス応用であるが，強誘電体は分極履歴現 象のみならず, 大誘電率やその電界変化, 焦電性, 圧電性, 電気光学効果, 光起電力効果, 電気抵抗の雾囲気力゙ス変化 など注目される現象が多い。さらに最近，低温で合成可能 な有機強誘電体薄膜や強誘電性, 強磁性, 強弾性を併せ持 つマルチフェロイクス薄膜が新しい物質として注目され, 大きな展開が期待されている。

これらの現象を利用した応用として，大誘電率を利用し たキャパシタそして電界変化を利用による $\mu$ 波チューナブ ルフィルタ，また，Si Micro-machining 技術を用いて作製さ れた $\mu \mathrm{m}$ オーダー厚の membrane 上の強誘電体薄膜による MEMS (Micro Electro Mechanical System) 素子応用がある。 これには，焦電性を利用した赤外線センサや，圧電性を利 用した超音波センサ，インクジェットプリンタ，マイクロ ミラーがある。さらに, 電気光学効果を用いて IC 間の高速

\footnotetext{
* 大阪大学大学院基礎工学研究科システム創成専攻電子光科学 領域

产560-8531 大阪府豊中市待兼山町 1-3

Osaka University, Graduate School of Engineering Science

1-3 Machikaneyama, Toyonaka, Osaka 560-8531
}

光信号転送や光集積回路などの応用も期待されている。マ ルチフェロイクスでは電界制御の磁気光素子や多值メモリ 等の応用が期待される。

ここでは，このようにして開発され，また今後期待され ている代表的な強誘電体薄膜薄膜の作製, 物性についての 現況について概説したい。

\section{2. $\mathrm{PZT}, \mathrm{PbTiO}_{3}$ 薄膜の極薄化, 強誘電性制御およ び低温成長}

PZT $\left(\mathrm{PbZr}_{\mathrm{x}} \mathrm{Ti}_{1-\mathrm{x}} \mathrm{O}_{3}\right)$ は，メモリ応用は勿論赤外線センサ, 圧電センサやアクチュエータ, 電気光学デバイスなど電子 応用への大きな期待から最もよく研究がなされた材料であ る。この PZT の薄膜化はスパッタリング, レーザアブレー ション法, ゾルーゲル法, MOCVD (有機金属気相成長) 法 を始めとしてこれまで多くの研究がなされてきた。なかで も, MOCVD は, 低い基板ダメージ, 容易な組成制御, 大 面積化可能, 高速堆積, 良好なステップカバレージ等の特 長から素子作製のための強誘電体薄膜作製法としても優れ ている。PZT 膜や $\mathrm{PbTiO}_{3}$ 膜は MOCVDにより研究が進んで おり，以下に最近のトピックスを述べる。

$\langle 2 \cdot 1\rangle$ 成長初期の島状成長と極薄膜 ここで，薄膜 の構造，物性に大きく影響するのは，基板の結晶性，配向 性であり, その初期核発生が重要なポイントとなる。また, 初期核はナノサイズであり, 従来からの強誘電性発現につ いてサイズ効果が問題となっていた。最近, 清水らは $\mathrm{SrTiO}_{3}$ や $\mathrm{Pt}$ 基板上に MOCVD により $\mathrm{PbTiO}_{3}$ や PZT を短時間成長 させ自己集合化現象によりナノサイズの島構造を形成し, その成長様式や物性について調べた(1)〜(3)。AFM 観察によ り，自己集合島は基板の配向性に沿ってごく初期には高さ， 幅両者とも増加, 島の密度が減少し, その後 2 次元的な成 長が支配的となってくることを示した。異なる面方位(111), (110), (100)の $\mathrm{SrTiO}_{3}$ 単結晶基板上に $\mathrm{Pt}$ 膜続いて $\mathrm{PbTiO}_{3}$ 膜を 
(111)
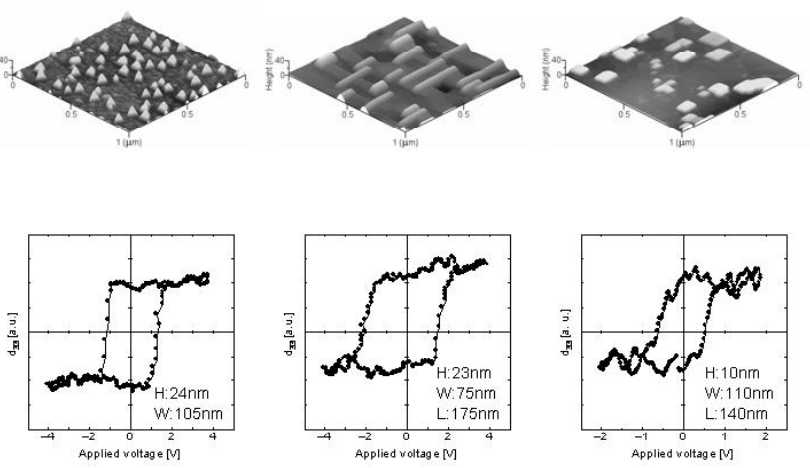

図 1 (111), (110), (100) $\mathrm{SrTiO}_{3}$ 基板上の $\mathrm{PbTiO}_{3}$ 膜島状構造と 圧電応答ヒステリシス

Fig. 1. Microscopic Image of island-like structure of $\mathrm{PbTiO}_{3}$ thin films deposited on (111), (110), (100) $\mathrm{SrTiO}_{3}$ substrates

成長させたときの表面形状を図 1 に示す。(111), (110), (100) の晶癖に対応して三角錐, 屋根型横長直方体, 正方形柱構 造のナノサイズ構造が見られる。これらのナノサイズ島の 圧電応答の電圧依存性も図 1 にあるようにヒステリスを有 し, 強誘電性を示唆している。膜厚が 1.5-9nm の構造におい てもヒステリシスが観測された。さらに, 成長を進め, 膜 厚 $20 \mathrm{~nm}$ の PZT 膜において分極ヒステリシスが観測され, 薄膜におけるサイズ効果に大きな問題が生じないことを示 唆した。

〈2·2〉結晶配向性制御による分極ヒステリシスの改善 MOCVD $の$ PZT 膜は(100) $\mathrm{SrRuO}_{3} / \mathrm{SrTiO}_{3}$ 基板上には(100) と(001)配向のみが成長するが，製膜温度と膜厚を変えるこ とで(001)面体積比 $(\mathrm{V}(001) /[\mathrm{V}(001)+\mathrm{V}(100)])$ は制御でき $る^{(4)(5)}$ 。(001)体積比 1 の PZT 膜が高温, 極薄の場合に得ら れ，その D-E ヒステリシスは図 2 に示寸ように角型比が良 いものとなっている。残留分極 $\operatorname{Pr}$ は(001)面の体積比に線形 の依存性を示し, 分極方向面(001) 配向が分極増加に有効 であることを示している。

〈2·3〉水熱処理による PZT 薄膜の低温作製 現在, FeRAM に使われている PZT や SBT $\left(\mathrm{SrBi}_{2} \mathrm{Ta}_{2} \mathrm{O}_{15}\right)$ 薄膜作製 には MOCVD, ゾルーゲル法, スパッタリング法などいず れの方法を用いても $600^{\circ} \mathrm{C}$ 程度の高温処理を必要としてい る。しかし，信号処理を行う LSI には通常 $\mathrm{Al}$ 金属膜配線が 使われており，その融点の $450^{\circ} \mathrm{C}$ 超えるため強誘電体薄膜 を LSI のフロントプロセスで作製した後に金属配線を行わ ねばならず，污染を考慮したプロセスラインを必要として いる。そこで $400^{\circ} \mathrm{C}$ 以下で強誘電体薄膜ができればエンドプ ロセスにもってこれ製造上非常に有利となる。

水熱処理は, 図 3 に示寸ようなオートクレーブ中の容器 内の水溶液に基板を浸漬し密閉して $100-300^{\circ} \mathrm{C}$ 程度で処理 することにより酸化物結晶を得る方法で，PZT のゲル膜を $\mathrm{KOH}$ と $\mathrm{Pb}(\mathrm{OH})_{2}$ 混合溶液中で水熱処理することにより結晶 化することができる(6)(7)。図 4 に示すように PZT ゲル膜の XRD には基板のPt のピークのみしか見られないが， $160^{\circ} \mathrm{C}$,

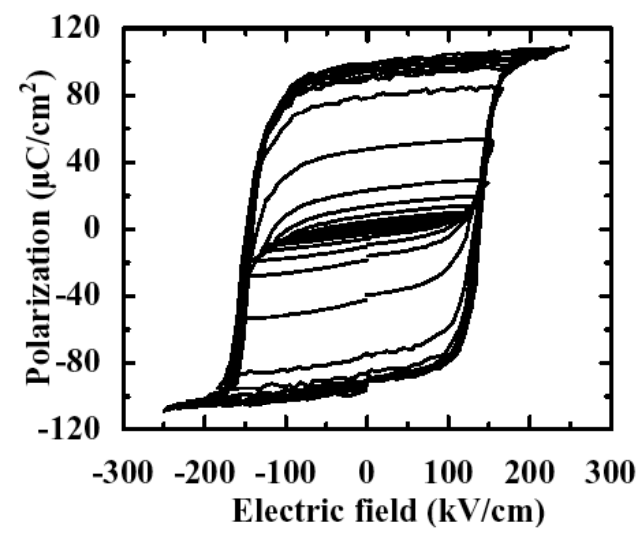

図 2 (001)面の体積比が 1 の場合の MOCVD PZT 薄膜の 分極ヒステリシス

Fig. 2. Polarization hysteresis of MOCVD PZT thin films having (100) volume ratio of 1

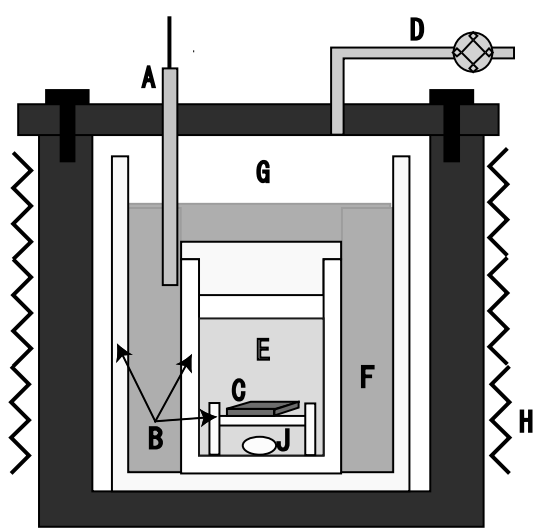
(A) 整雷対
(B) テフロン
(C) 基板
(F) 脱イオン水
(E) 水溶液
(G) 蒸気
(H) ヒータ

図 3 水熱処理用オートクレーブの構造

Fig. 3. Structure of Autoclave



図 $4 \mathrm{PZT}$ ゲル膜と $\mathrm{KOH}$ と $\mathrm{Pb}(\mathrm{OH})_{2}$ 混合溶液中で 水熱処理した膜の XTD パターン

Fig. 4. XRD patterns of gel-PZT film and PZT film treated in mixture solution of $\mathrm{KOH}$ and $\mathrm{Pb}(\mathrm{OH})_{2}$ 
60 分水熱処理により(111)の大きなピークが現れ, 結晶化し たことがわかる。水熱処理した PZT 膜を $400^{\circ} \mathrm{C}, 10$ 分処理 することにより分極ヒステリシスが観測されるようにな る。 $\mathrm{KOH}$ は半導体プロセスでは用いることができないため $\mathrm{Ba}(\mathrm{OH})_{2}$ と $\mathrm{Pb}(\mathrm{OH})_{2}$ の混合溶液を用いて PBZT $((\mathrm{Pb}, \mathrm{Ba})$ $\left.(\mathrm{Zr}, \mathrm{Ti}) \mathrm{O}_{3}\right)$ 膜が作製されている。

\section{3. $\mathrm{Bi}$ 層状構造強誘電体薄膜の元素置換と自然超 格子構造による分極量の増大}

〈3・1〉 元素置換による $\mathrm{Bi}_{4} \mathrm{Ti}_{3} \mathrm{O}_{12}$ 膜の分極の増大 $\mathrm{Bi}$

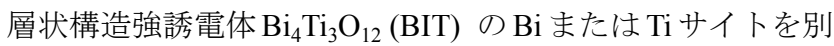
の元素で置き換えることにより分極量, 坑電界の制御が行 われた。MOCVD においても実現されているがここでは化 学溶液プロセスによる結果を示す。化学溶液プロセスでは, 溶液を塗布, 乾燥, 仮焼成, 本焼成などと真空装置を用い ずに簡便に薄膜を作製できるところから，よく使われてい る。 $\mathrm{Bi}$ を $3 \%$ 過剰にし少量の希土類金属で Bi の一部を置換 した組成で金属アルコキシドを混合して前駆体溶液を調整 し，コーティング，焼成により $\mathrm{Pt}$ 膜基板上に製膜 した ${ }^{(8)}$ 。図 5 は La, Nd, Sm, Gd で置換した BIT 膜 (BLT, BNT, BST, BGT) と置換無しのBIT 薄膜の D-E ヒステリシス を示す。BLT, BNT で分極量の増大が得られている。さらに, $\mathrm{Ti}$ の一部を $\mathrm{Si}$ や $\mathrm{Ge}$ で置換した薄膜でも分極の増大が確認 された ${ }^{(9)}$ 。

$\langle 3 \cdot 2\rangle \quad \mathrm{Bi}$ 層状構造強誘電体自然超構造格子薄膜 $\quad \mathrm{Bi}$ 層状構造強誘電体 (BLSF) は単層または複数層（ $m$ 個）の 擬ペロブスカイト構造を $\mathrm{Bi}_{2} \mathrm{O}_{2}$ 層で挟まれた層状構造とな っており，その自発分極は擬ペロブスカイト構造の層面内 の回転ならびに面に垂直方向の傾きに由来するものと考え られている。異種の擬ペロブスカイト構造が超格子構造を 構成すれば $\mathrm{Bi}_{2} \mathrm{O}_{2}$ 層を通じて格子定数の違いにより歪が生

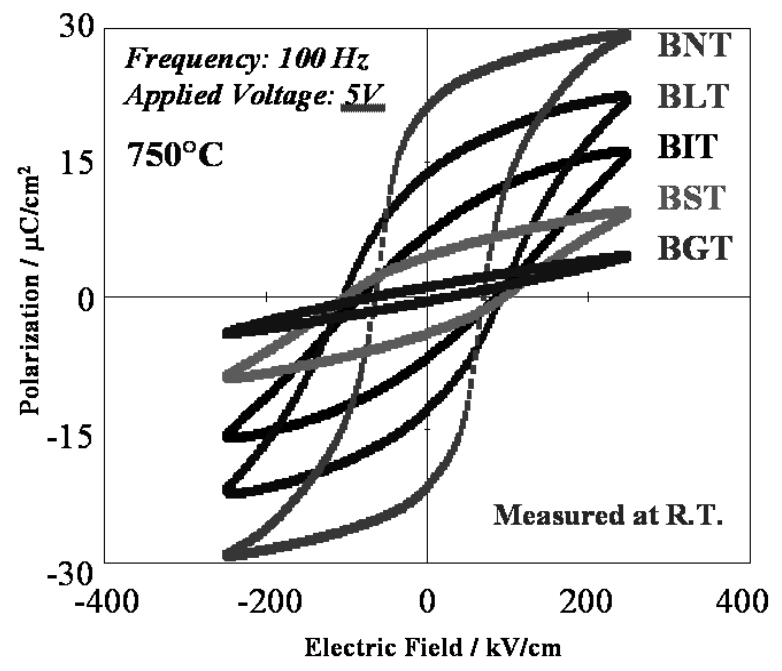

図 $5 \mathrm{La}, \mathrm{Nd}, \mathrm{Sm}, \mathrm{Gd}$ で置換した $\mathrm{Bi}_{4} \mathrm{Ti}_{3} \mathrm{O}_{12}$ 膜の分極 ヒステリシス

Fig. 5. Hysteresis of $\mathrm{Bi}_{4} \mathrm{Ti}_{3} \mathrm{O}_{12}$ thin films substituted by La, $\mathrm{Nd}, \mathrm{Sm}$ and Gd
じ，分極量の変化が期待できる。

$m$ の異なる BLSF を等量混合して作製したセラミックタ 一ゲットを用いた PLD 法により薄膜作製が試られた ${ }^{(10)(11)}$ 。 図 6 は $\mathrm{Bi}_{4} \mathrm{Ti}_{3} \mathrm{O}_{12}(\mathrm{BIT}, m=3)$ と $\mathrm{SrBi}_{4} \mathrm{Ti}_{4} \mathrm{O}_{15}(\mathrm{SBTi}, m=4)$ 混合 ターゲットより得られた薄膜の XRD を示す。 BIT と SBTi のピーク位置外に大きなピークが見出され，これは BIT と SBTi の 1 unit の和にほぼ等しい。さらに逆格子マッピング や図 7 に示寸 TEM 像から BIT と SBTi が交互に積層された 超格子構造となっていることがわかった。さらに, $\mathrm{Bi}_{3} \mathrm{NbTiO}_{9}$ (BTN, $m=2)$ と BIT の超格子膜では, 2 units の BTN と 1 unit の BIT が積層した変則的な構造ととることがわかった。

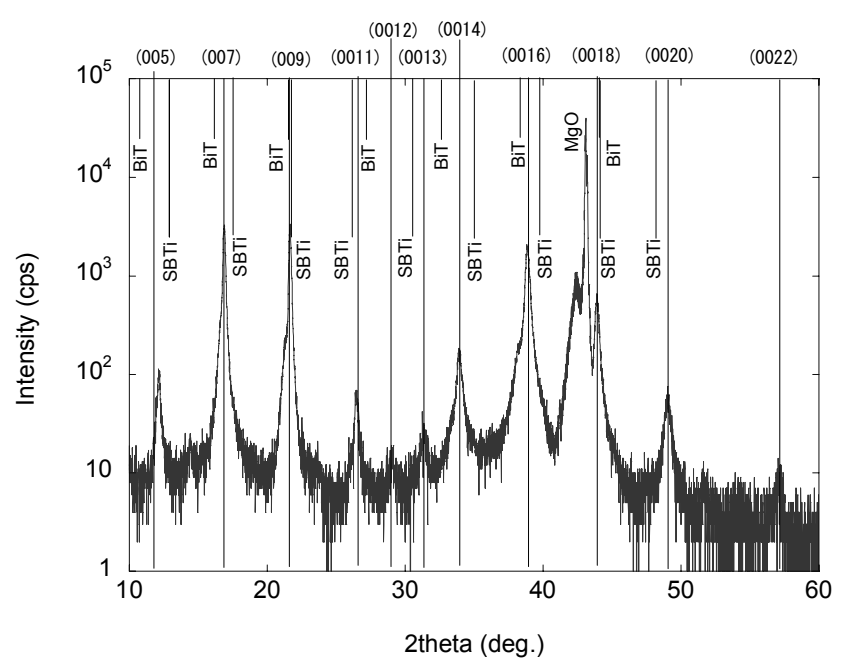

図 6 BIT-SBTi 自然超格子膜の XRD パターン

Fig. 6. XRD pattern of 6BIT-SBTi natural super lattice

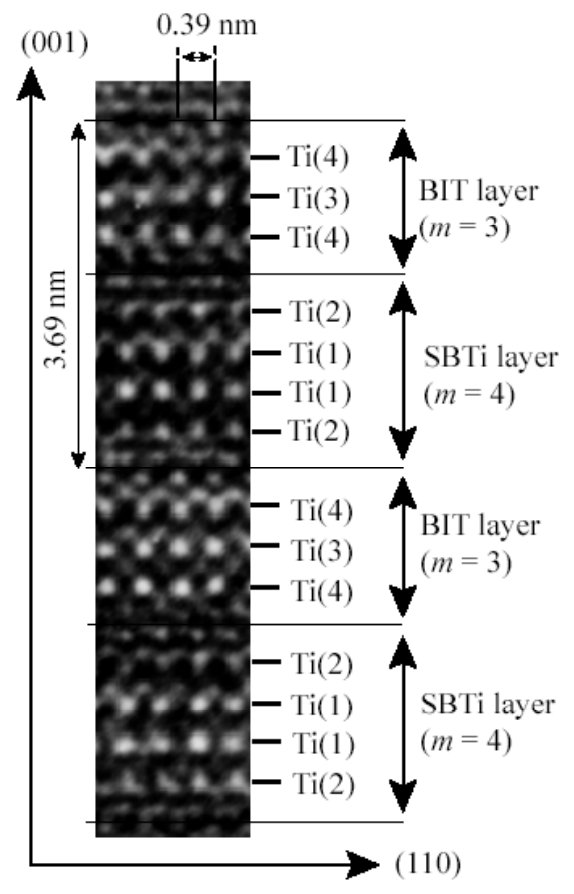

図 7 BIT-SBTi 自然超格子膜の TEM 像

Fig. 7. TEM image of BiT-SBTi natural superlattice film 
BIT-SBTi 超格子膜の D-E ヒステリシスは $750^{\circ} \mathrm{C}, 45$ 分の熱処 理により分極量が増加し, 角型比が改善されている。また, $m=1$ の $\mathrm{Bi}_{2} \mathrm{MoO}_{6}$ と $m=2$ の $\mathrm{Bi}_{3} \mathrm{TiNbO}_{9}$ の薄膜では成長条件に より通常の 1 unitずつの超格子構造と 2 units と 1 unitずつの 超格子構造の 2 種類の構造をとる。

\section{4. マルチフェロイック薄膜}

強誘電性, 強磁性あるいは強弾性を併せ持つ物質がマル チフェロイック材料として注目されている。

〈4·1〉 $\mathrm{BiFeO}_{3}$ 膜の強誘電分極 $\mathrm{BiFeO}_{3}$ は PLD 法に より酸素雰囲気中で $\mathrm{Pt} / \mathrm{TiO}_{2} / \mathrm{SiO}_{2} / \mathrm{Si}$ 基板上に成長され た ${ }^{(12)(13)}$ 。薄膜はペロブスカイト単層からなる多結晶 $\mathrm{BiFeO}_{3}$ となっている。絶縁性は基板温度，雰囲気ガス，ガス圧な どの成長条件を最適化することにより大きく依存する。図 8 に最適化された電流密度一電界特性示しており，80K では $1033 \mathrm{kV} / \mathrm{cm}$ で電流密度が $3 \times 10^{-4} \mathrm{~A} / \mathrm{cm}^{2}$ と大きく低減されて いる。誘電率と誘電正接は, RT でそれぞれ 134 と 0.048 , $80 \mathrm{~K}$ で 95 と 0.021 となる。これらの值は温度減少や測定周 波数増加とともに徐々に減少する。さらに, 誘電率はバタ フライ曲線状のヒステリシスを示す。

室温と $80 \mathrm{~K}$ で得られた分極ヒステリシス特性を図 9 に示 す。ヒステリシス特性は飽和した曲線となり, その自発分 極 $P_{s}$, 残留分極 $P_{r}$, 坑電界 $E_{c}$ は, 室温で $667 \mathrm{kV} / \mathrm{cm}$ 印加時

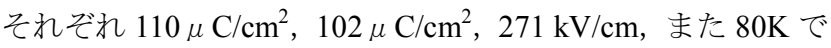
は $1033 \mathrm{kV} / \mathrm{cm}$ の電界が印加でき $P_{s} 166 \mu \mathrm{C} / \mathrm{cm}^{2}, P_{r} 152$ $\mu \mathrm{C} / \mathrm{cm}^{2}, E_{c} 308 \mathrm{kV} / \mathrm{cm}$ となり, 分極值は $\mathrm{PZT} や \mathrm{PbTiO}_{3}$ の 最大分極值の約 1.5 倍となる。印加電圧の周波数が $1 \mathrm{~Hz}$ 以上 ではヒステリシスはほとんど変わらず，リーク電流も小さ いことからこの特性は分極反転によるものと考えられる。

さらに, AFM で得られた圧電応答の電界依存性において もヒステリシスが得られ, 圧電係数は $66 \mathrm{pm} / \mathrm{V}$ で Ti-rich PZT と同等程度であり，非鉛圧電体としても期待できる。さら に電界印加時の面分布からドメインの核成長が観察され た。磁化特性は本来反強磁性であるが，わずかなスピンの キャンティングによって弱い強磁性を有し，室温で飽和性

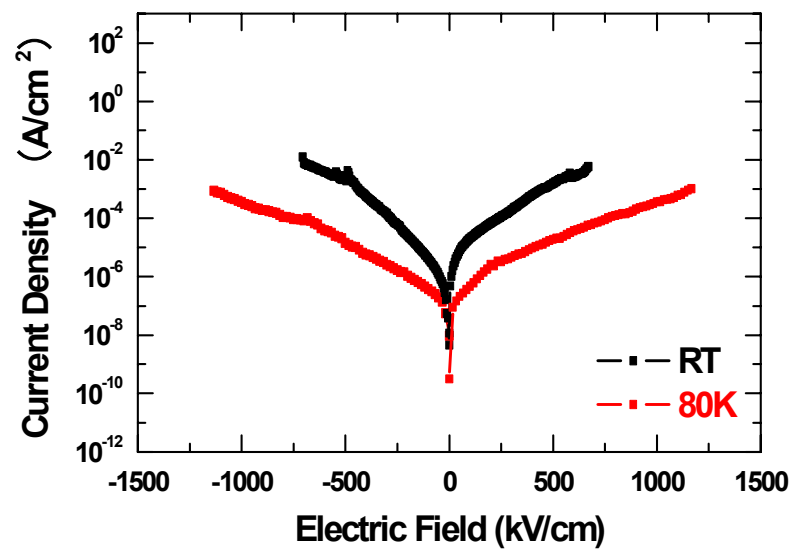

図 $8 \mathrm{BiFeO}_{3}$ 薄膜の室温, $80 \mathrm{~K}$ での電流密度一電界特性

Fig. 8. Polarization hysteresis of $\mathrm{BiFeO}_{3}$ thin film
の良い磁気ヒステリシス特性が得られた。最大印加磁場が $10 \mathrm{kOe}$ の時飽和磁化は $40 \mathrm{emu} / \mathrm{cm}^{3}$ となった。

さらに tetragonal phase $\mathrm{BiFeO}_{3}$ の構造を第 1 原理計算によ り理論解析した ${ }^{(14)}$ 。Tetragonality の基板面格子定数依存性の 理論值と実験值は比較的よく一致している。最適化構造で の Berry phase の自発分極理論值は $143.5 \mu \mathrm{C} / \mathrm{cm}^{2}$ となり，実 験值に近いことがわかった。

マルチフェッロイック材料に期待されているのは, 磁気 効果を電圧で制御をしたり，その逆を行えるという電気磁 気効果である。図 10 は $\mathrm{BiFeO}_{3}$ 薄膜の分極ヒステリシスの磁 場依存性を示す。磁場無しと $1.1 \mathrm{~T}$ の磁場があるヒステリシ スが僅かに変化しその可能性を示唆しているが(15), もっと

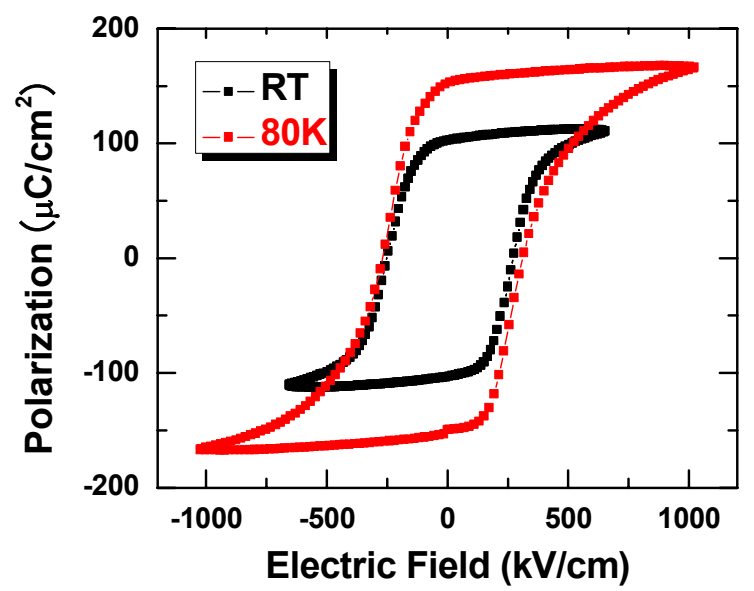

図 $9 \mathrm{BiFeO}_{3}$ 薄膜の室温, $80 \mathrm{~K}$ での分極ヒステリシス

Fig. 9. Polarization hysteresis of $\mathrm{BiFeO}_{3}$ thin film measured at room temperature and $80 \mathrm{~K}$
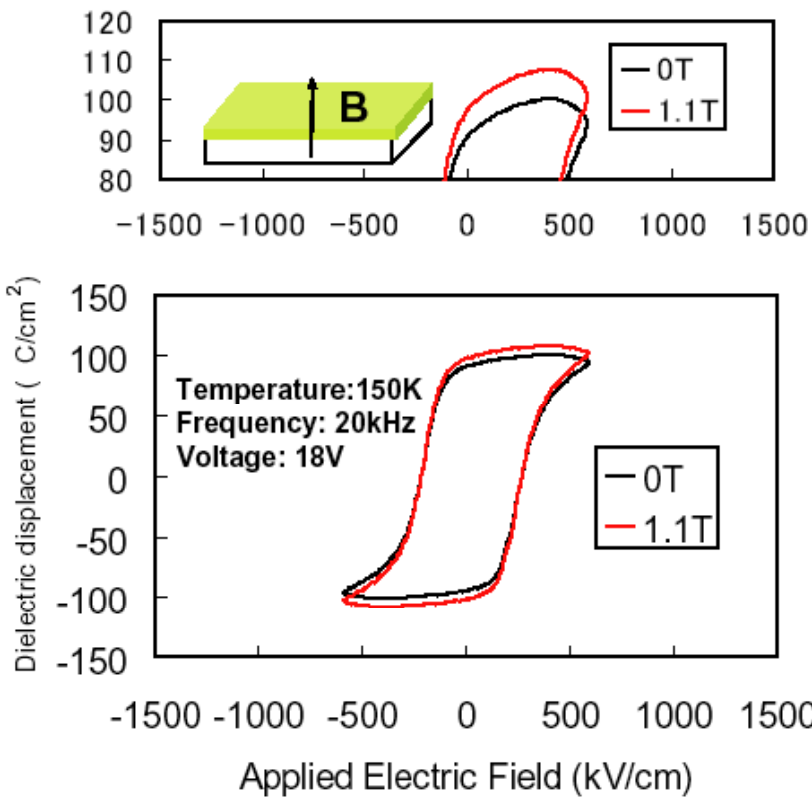

図 $10 \mathrm{BiFeO}_{3}$ 薄膜の分極ヒステリシスの磁場依存性 (上の図は拡大図)

Fig. 10. Magnetic field dependence of $\mathrm{BiFeO}_{3}$ thin film (Upper figure shows enlarged characteristics) 
大きい効果が物性面，応用面からも期待されている。

〈4·2〉 $\mathrm{YMnO}_{3}$ 薄膜 $\mathrm{YMnO}_{3}$ は六方晶の結晶構造で, $\mathrm{c}$ 軸方向に分極を持つ強誘電性, 面内方向に反強磁性を有す るマルチフェロイック物質である。レーザアブレーション 法やゾルーゲル法により $\mathrm{Pt}$ 膜上に $\mathrm{YMnO}_{3}$ 薄膜が作製され, 強誘電性と強磁性の共存が確認されている。さらに $100 \mathrm{~K}$ 付 近の誘電率の印加電圧依存性において磁場を印加すること により僅かに誘電率が変化することを見出し, 磁気電気相 互作用があると報告されている(16)。

\section{5. $P(V D F-T r F E)$ 高分子膜}

ポリ弗化ビニリデン PVDF (polyvinylidenefluoride) はその フィルムを延伸することにより比較的大きな強誘電性を示 す。この PVDF と三弗化エチレン (TrFE, Trifluoroethylene) を共重合体 P (VDF-TrFE) はスピンコーティングと低温熱 処理により容易に低温で作製可能な有機強誘電体薄膜とな る。しかし，これまで報告された P (VDF-TrFE) は膜は坑電 界が高く, 実用性に乏しかったが, 最近数十 nm の膜厚の薄 膜において坑電界の低いものの作製に成功し, 不揮発性入 モリや圧電デバイスへの応用が期待されている(17)。

\section{6. まとめ}

センサ，アクチュエータ，メモリ用電子材料として期待 される強誘電体薄膜についての最近の動向について紹介し た。強誘電性は前述のように基板との組み合わせ, 分子構 造の変化, 元素置換, 欠陥制御などにより改善される。こ れは強誘電体の物性が構成元素の格子内位置の微小変位に よるもので, 構造変化に非常に敏感であることによると考 えられる。さらに, これら強誘電性と強磁性の両者の物性 を有し, その相互作用も期待できるマルチフェロイクスに ついても紹介した。今後もデバイス側からの要求に対応し た新しい発見, 展開が輩出されることが期待される。

\section{謝 辞}

本稿作成にあたり，兵庫県立大学清水勝氏，東京工業大 学 舟窪 浩氏, 名古屋大学 坂本 渉氏に資料提供いた だき，感謝致します。

(平成 19 年 9 月 21 日受付)

\section{文献}

(1) H. Nonomura, H. Fujisawa, M. Shimizu, H. Niu, and K. Honda : Jpn. J. Appl. Phys., Vol.42, p.5918 (2003)

(2) M. Shimizu, H. Nonomura, H. Fujisawa, H. Niu, and K. Honda : Abs. $15^{\text {th }}$ Int. Symp. On Intergrated Ferroelectrics, p.440 (2003)

(3) H. Fujisawa, M. Okaniwa, M. Shimizu, and H. Niu : Jpn. J. Eur.Ceram. Soc., Vol.24, p.1641 (2004)

(4) H. Morioka, G. Asano, T. Oikawa, H. Funakubo, and K. Saito : Appl. Phys. Lett., Vol.82, p.4761 (2003)

( 5 ) H. Morioka, G. Asano, T. Oikawa, H. Funakubo, and K. Saito : Appl. Phys. Lett., Vol.82, p.4761 (2003)

(6) Z. Wei, K. Yamashita, and M. Okuyama : Jpn. J. Appl. Phys., Vol.40, p.5539 (2001)

( 7 ) Z. Wei, M. Noda, and M. Okuyama : Jpn. J. Appl. Phys., Vol.41, p.6619 (2002)

(8) M. Yamada, N. Iizawa, T. Yamaguchi, W.Sakamoto, K. Kikuta, T. Yogo, T. Hayashi, and S. Hirano : Jpn. J. Appl. Phys., Vol.42, p.5222 (2003)

(9) W. Sakamoto, N. Iizawa, T. Yogo, T. Hayashi, and S. Hirano : Jpn. J. Appl. Phys., Vol.42, p.L1384 (2003)

(10) A. Shibuya, M. Noda, M. Okuyama, H. Fujisawa, and M. Shimizu : Appl. Phys. Lett., Vol.82, p.784 (2003)

(11) A. Shibuya, S. Ikemori, W. B. Wu, M. Noda, and M. Okuyama : Appl. Phys. Lett., Vol.83, p.1411 (2003)

(12) K-W Yun, D. Ricinschi, T. Kanashima, M. Noda, and M. Okuyama : Jpn. J. Appl. Phys., Vol.43, p.L647-648 (2004)

(13) K-W Yun, M. Noda, and M. Okuyama : Appl. Phys. Lett., Vol.83, p.3981 (2003)

(14) D. Ricinschi, K-W Yun, and M. Okuyama : J. Phys. Condense, Vol.18, p.L97 (2006)

(15) S. Nakashima, K-W Yun, Y. Nakamura, and M. Okuyama : Mt. Res. Soc. Symp. Proc., Vol.966, T03-13 (2007), Boston (2007)

(16) 藤村紀文・吉村 武:「日本欽属学会講演概要」, p.72, 広島 (2005-9)

(17) 藤崎寿美子 - 石原 宏 - 藤崎芳久 : 第 68 回応用物理学会学術講演 会」, 4aZL-9 (2007-9)

奥 山 雅 則 （正員） 1946 年 3 月 4 日生。1973 年大阪大学

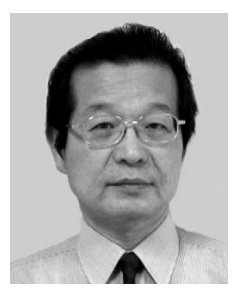
大学院基礎工学研究科博士課程電気工学分野 修了。1973 年日本学術振興会奨励研究員。1974 年 4 月大阪大学基礎工学部電気工学科助手。 1991 年大阪大学基礎工学部電気工学科教授。 1997 年より大阪大学 大学院基礎工学研究科教 授。強誘電体・機能性誘電体薄膜の作製評価と 電子デバイス・センサへの応用。センシング技 術応用研究会, 次世代センサ協議会, 応用物理学会, 日本物理学会, 日本表面科学会, 日本赤外線学会, 日本放射光学会, 材料学会, IEEE 各会員。 